\title{
Germline E-cadherin mutations in hereditary diffuse gastric cancer: assessment of 42 new families and review of genetic screening criteria
}

\author{
A R Brooks-Wilson, P Kaurah, G Suriano, S Leach, J Senz, N Grehan, Y S N Butterfield, J Jeyes, \\ J Schinas, J Bacani, M Kelsey, P Ferreira, B MacGillivray, P MacLeod, M Micek, J Ford, W Foulkes, \\ K Australie, C Greenberg, M LaPointe, C Gilpin, S Nikkel, D Gilchrist, R Hughes, C E Jackson, \\ K G Monaghan, M J Oliveira, R Seruca, S Gallinger, C Caldas*, D Huntsman*
}

See end of article for

authors' affiliations

J Med Genet 2004;41:508-517. doi: 10.1136/jmg.2004.018275

Correspondence to:

D Huntsman, B.C. Cancer

Agency, 600 West 10th

Avenue, Vancouver, BC,

Canada V5Z 4E6;

dhuntsma@bccancer.bc.ca

Correspondence to:

C Caldas, Department of

Oncology, University of

Cambridge, Hutchison/

MRC Research Centre,

Level 3, Addenbrooke's

Hospital, Cambridge

CB2 2XŹ, UK; cc234@

cam.ac.uk

Revised version received 9 January 2004

Accepted for publication

19 February 2004
Background: Mutations in the $\mathrm{E}$-cadherin $(\mathrm{CDH} 1)$ gene are a well documented cause of hereditary diffuse gastric cancer (HDGC). Development of evidence based guidelines for $C D H 1$ screening for HDGC have been complicated by its rarity, variable penetrance, and lack of founder mutations.

Methods: Forty three new gastric cancer (GC) families were ascertained from multiple sources. In 42 of these families at least one gastric cancer was pathologically confirmed to be a diffuse gastric cancer (DGC); the other family had intestinal type gastric cancers. Screening of the entire coding region of the $\mathrm{CDH} 1$ gene and all intron/exon boundaries was performed by bi-directional sequencing.

Results: Novel mutations were found in 13 of the 42 DGC families ( $31 \%$ overall). Twelve of these mutations occur among the 25 families with multiple cases of gastric cancer and with pathologic confirmation of diffuse gastric cancer phenotype in at least one individual under the age of 50 years. The mutations found include small insertions and deletions, splice site mutations, and three non-conservative amino acid substitutions (A298T, W409R, and R732Q). All three missense mutations conferred loss of E-cadherin function in in vitro assays. Multiple cases of breast cancers including pathologically confirmed lobular breast cancers were observed both in mutation positive and negative families.

Conclusion: Germline truncating $\mathrm{CDH} 1$ mutations are found in $48 \%$ of families with multiple cases of gastric cancer and at least one documented case of DGC in an individual under 50 years of age. We recommend that these criteria be used for selecting families for $\mathrm{CDH1}$ mutational analysis.
G astric cancer is one of the leading causes of cancer death worldwide. ${ }^{1}$ There are two major histological variants: (1) diffuse gastric cancer (DGC) and (2) intestinal type gastric cancer (IGC). ${ }^{2}$ In the diffuse form, a malignant infiltrate containing cells that have a large globule of intracellular mucin and an eccentric nucleus permeates the wall of the stomach, often spreading under histologically normal mucosa. In the more common intestinal type, the malignant cells exist in glandular structures with variable levels of differentiation. Approximately $10 \%$ of gastric cancers have a mixed phenotype; the genetic basis for the phenotypic heterogeneity in these cases is believed to be somatic Ecadherin loss in the diffuse gastric cancer component of such tumours. ${ }^{3}$ The relative frequency of diffuse and intestinal cancers varies with the population surveyed and the classification criteria used. ${ }^{4}$

A small proportion of diffuse gastric cancers, perhaps as few as $1 \%$, occur in families with autosomal dominant gastric cancer susceptibility. ${ }^{5}$ Although only a minority of gastric cancers are hereditary, the identification of such cases offers the opportunity to provide genetic counselling, genetic testing for gastric cancer susceptibility, and gastric cancer risk reduction strategies to as yet unaffected family members at risk for the development of gastric cancer. Gastric cancer is usually lethal if diagnosed at a late stage $(<20 \% 5$ year survival) but is curable if resected before invasion through the gastric wall ( $>90 \% 5$ year survival $\left.{ }^{1}\right)$. Unfortunately, most gastric cancers, and DGCs in particular, become symptomatic only when they are incurable. Effective treatment of familial gastric cancer, therefore, depends on the presymptomatic identification of individuals at risk for this cancer.

The majority of families with autosomal dominant gastric cancer susceptibility have diffuse type gastric cancer. Hereditary diffuse gastric cancer (HDGC) has also been noted to occur in families in combination with breast cancer, particularly lobular breast cancer (LBC). ${ }^{6}$ In 1999 the International Gastric Cancer Linkage Consortium (IGCLC) defined hereditary diffuse gastric cancer by clinical criteria that include: (1) any family with two or more documented cases of diffuse gastric cancer in first or second degree relatives with one case under the age of 50, or (2) three documented diffuse gastric cancers in first or second degree relatives at any age. ${ }^{7}$

Germline mutations in the E-cadherin gene (epithelial cadherin, CDH1, OMIM\# 192090) have been demonstrated to underlie disease in some but not all HDGC families, but not in hereditary intestinal type gastric cancer families. ${ }^{7}$ $\mathrm{CDHl}$ mutations were first described in three Maori families with autosomal dominant diffuse gastric cancer. ${ }^{8}$ Since then, germline loss of function mutations have been demonstrated

\footnotetext{
Abbreviations: FAP, familial adenomatous polyposis; FFPE, formalinfixed paraffin embedded; HDGC, hereditary diffuse gastric cancer; HNPCC, hereditary non-polyposis colon cancer; IGC, intestinal type gastric cancer; LCIS, lobular breast carcinoma in situ; PJS, Peutz-Jeghers syndrome
} 
to underlie approximately $30 \%$ of HDGC in families of various ethnic backgrounds. ${ }^{10}$ E-cadherin is a member of the cadherin family of adhesion molecules, which are transmembrane glycoproteins mediating calcium-dependent cell-cell adhesion. ${ }^{11}$ E-cadherin is critical for establishing and maintaining polarised and differentiated epithelia during development. It also plays important roles in signal transduction, differentiation, gene expression, cell motility, and inflammation. Somatic loss of E-cadherin expression is considered to be a defining feature of both DGC and lobular breast cancer. ${ }^{12} 13$

We ascertained 43 apparent cases of hereditary gastric cancer and screened them for germline E-cadherin mutations to determine the optimum criteria for clinical testing and to identify other cancer risks associated with germline Ecadherin mutations.

\section{METHODS}

\section{Families and patients}

A total of 43 families were identified: 18 from Canada, five from the United States and 20 from the United Kingdom. Ethnicity was known in 20/43 families. Of these, 15 were of Northern European descent. The others were of Spanish, Haida, French-Canadian, and Italian descent. The criteria used for ascertainment and testing are described in table 1. Criteria 1 and 2 are the IGCLC criteria for HDGC families. Criteria $1 \mathrm{~A}$ and $2 \mathrm{~A}$ are similar to $\mathrm{l}$ and 2 but have been relaxed to account for the difficulty in obtaining pathologic confirmation on referral cases. The age of onset of GC in these families ranged from 9 to 65 years of age. Other cancers seen in these families include lobular breast, colon, prostate, ovarian, head and neck, and oesophageal cancers. Examples of two of the HDGC families are shown in figs 1 and 3A. Constitutional genomic DNA was extracted by standard methods from a blood sample from one affected individual of each family, usually the proband. In two families, blood samples from an as yet unaffected family member were used (table 2); in one family, an obligate carrier was screened because DNA of an affected family member was unavailable and, in another family, an at risk first degree relative was screened. In both cases, a mutation was found. The investigations were performed after approval by the Clinical Research Ethics Board of the University of British Columbia. Informed consent was obtained from each subject, or next of kin in the case of a deceased affected individual.

\section{DNA extraction}

Patients' peripheral blood samples were collected in EDTA tubes. The buffy coat layers of whole blood were treated with Puregene RBC lysis solution (Gentra Systems, MN, USA) and cell wash. A portion of white cells was used for DNA extraction and remaining cells were stored in freezer media. Puregene DNA Purification Kit (Gentra Systems) was used and the manufacture's manual was followed for genomic DNA isolation.

Paraffin embedded sections from normal tissue were deparaffinised with xylene for $5 \mathrm{~min}$ at room temperature and centrifuged at $14000 \mathrm{rpm}$ for $3 \mathrm{~min}$. After removal of the xylene, the samples were treated with $100 \%, 70 \%$ and $50 \%$ ethanol series for rehydration. Pellets were dried and incubated with Proteinase $\mathrm{K}(10 \mathrm{mg} / \mathrm{ml}$ Proteinase $\mathrm{K}, \mathrm{l} \mathrm{M}$ $\mathrm{KCl}$, $1 \mathrm{M}$ Tris $\mathrm{pH} 8.0$, $1 \mathrm{M} \mathrm{MgCl}_{2}$ ) at $56^{\circ} \mathrm{C}$ overnight and then boiled to inactivate the enzyme and centrifuged at $14000 \mathrm{rpm}$. The supernatant was purified by phenol/chloroform extraction. DNA was precipitated with $100 \%$ ethanol, dried at room temperature and resuspended with $\mathrm{dd}_{2} \mathrm{O}$.

\section{Variant detection sequencing}

Primers were designed using Primer 3 (http://www-genome. wi.mit.edu/cgi-bin/primer/primer3_www.cgi). Forward and reverse primers incorporated the -21MI3F (TGTAA AACGACGGCCAGT) or MI3R (CAGGAAACAGCTATGAC) extensions, respectively, at their $5^{\prime}$ ends. The sequences of all primers used in this study, and their annealing temperatures, are shown in table 3. PCR reactions were carried out in a volume of $20 \mu \mathrm{l}$ containing $10 \mathrm{ng}$ genomic DNA template, $1 \mathrm{mM} \mathrm{MgSO}_{4}, 0.5 \mu \mathrm{M}$ of each PCR primer, $2 \mathrm{mM}$ dNTPs, $1 \times$ Pfx Amplification Buffer and 0.25 U Platinum Pfx DNA polymerase (Invitrogen, ON, Canada). Thirty cycles of $30 \mathrm{~s}$ at $94^{\circ} \mathrm{C}, 30 \mathrm{~s}$ at a primer pair specific annealing temperature of $50-65^{\circ} \mathrm{C}$ and $1 \mathrm{~min}$ at $68^{\circ} \mathrm{C}$ were performed in programmable thermocyclers (MJ Research PTC-225 or Tetrads, Waltham, MA). A $3 \mu \mathrm{l}$ aliquot of each PCR reaction was run on a $2 \%$ agarose gel to confirm the size, quantity, and purity of each PCR product. The remaining $17 \mu \mathrm{l}$ of PCR product was purified using AmPure magnetic beads (Agencourt Bioscience, Beverly, MA) and eluted in a volume of $30 \mu \mathrm{l}$ of TE (Tris-EDTA pH 8.0) according to the manufacturer's instructions. A $2 \mu \mathrm{l}$ aliquot of purified PCR product was then cycle sequenced using Big Dye Terminator Mix V.3 at $0.25 \times$ chemistry in a total volume of $4 \mu \mathrm{l}$ (Applied Biosystems, Foster City, CA). Both forward $(-21 \mathrm{Ml} 3 \mathrm{~F}$ primer $)$ and

\begin{tabular}{|c|c|c|c|c|c|c|}
\hline Criteria no & Definition & Families (n) & $\begin{array}{l}\text { Truncating } \\
\text { mutations (n) }\end{array}$ & $\begin{array}{l}\text { Splice site } \\
\text { mutations (n) }\end{array}$ & $\begin{array}{l}\text { Missense } \\
\text { mutations (n) }\end{array}$ & $\begin{array}{l}\text { Total number of } \\
\text { mutations }\end{array}$ \\
\hline 1 & $\begin{array}{l}\text { Two or more documented cases of DGC in first degree } \\
\text { relatives, with at least one diagnosed before age } 50\end{array}$ & 15 & 5 & 1 & 2 & $8(53 \%)$ \\
\hline $1 \mathrm{~A}$ & $\begin{array}{l}\text { Two or more cases of GC, with at least one DGC } \\
\text { diagnosed before age } 50\end{array}$ & 10 & 3 & 1 & 0 & $4(40 \%)$ \\
\hline 2 & $\begin{array}{l}\text { Three or more documented cases of DGC in first degree } \\
\text { relatives, diagnosed at any age }\end{array}$ & 1 & 0 & 0 & 0 & 0 \\
\hline $2 \mathrm{~A}$ & $\begin{array}{l}\text { Three or more cases of GC, diagnosed at any age, with } \\
\text { at least one documented case of DGC }\end{array}$ & 3 & 0 & 0 & 0 & 0 \\
\hline 3 & $\begin{array}{l}\text { Isolated individual diagnosed with DGC at less than } 45 \\
\text { years of age }\end{array}$ & 9 & 0 & 0 & 0 & 0 \\
\hline 4 & $\begin{array}{l}\text { Isolated individual diagnosed with both DGC and lobular } \\
\text { breast cancer (no other criteria met) }\end{array}$ & 0 & 0 & 0 & 0 & 0 \\
\hline 5 & $\begin{array}{l}\text { One family member diagnosed with DGC and another } \\
\text { with lobular breast cancer (no other criteria met) }\end{array}$ & 3 & 0 & 0 & 0 & 0 \\
\hline 6 & $\begin{array}{l}\text { One family member diagnosed with DGC and another } \\
\text { with colon cancer (no other criteria met) }\end{array}$ & $1^{*}$ & 0 & 0 & 1 & $1(100 \%)$ \\
\hline 7 & Intestinal gastric cancer & 1 & 0 & 0 & 0 & 0 \\
\hline
\end{tabular}


reverse (M13R primer) directions were sequenced. Cycle sequencing reactions consisted of 30 cycles of $10 \mathrm{~s}$ at $96^{\circ} \mathrm{C}, 5 \mathrm{~s}$ at $52^{\circ} \mathrm{C}\left(-21 \mathrm{Ml} 3 \mathrm{~F}\right.$ forward primer) or $43^{\circ} \mathrm{C}(\mathrm{Ml} 3 \mathrm{R}$ reverse primer), and $3 \mathrm{~min}$ at $60^{\circ} \mathrm{C}$. Reaction products were precipitated with isopropyl alcohol, washed with $70 \%$ ethanol, and resuspended in $8 \mu \mathrm{l}$ of double distilled water before loading on ABI 3700 capillary sequencers. Sequence reads were base-called using Phred and sequence reads assembled with reference sequences using Phrap. ${ }^{14}{ }^{15}$ Contigs of sequence traces corresponding to each exon were examined using PolyPhred ${ }^{16}$ for detection of heterozygotes and visualised in Consed $^{17}$ to facilitate verification of sequence variants by examination of individual traces.

\section{Single strand conformation polymorphism (SSCP) analysis of $\mathrm{CDH} 1$ for formalin-fixed paraffin embedded (FFPE) DNA samples}

In four families (F10, F19, F20, and F21), only DNA extracted from paraffin tissue blocks was available. In these cases, the $\mathrm{CDHl}$ gene was screened by SSCP.

FFPE germline DNA from six samples were screened for CDHl mutations by PCR of all exons and intronexon boundaries followed by SSCP analysis on $8 \%$ polyacrylamide, $10 \%$ glycerol, and $0.5 \times \mathrm{TBE}$ gels. Primer sequences were based on those reported previously, ${ }^{13}$ except for exons 1-5, which were amplified using new primers (EXIF: 5'-TACGGGGGGCGGTGCCT-3'; EXIR: 5'-CTGGGG CGCGGAGCTTG-3'; EX2F: 5'-TACCCCGGTTCCATCTACC TTT-3'; EX2R: 5'-GCAATTTCTCGGCCCCTTTCC-3'; EX3AF: 5'-GTCTTTAATCTGTCCAATTTCC-3'; EX3AR: 5'-GCGTAGA CCAAGAAATGGAT-3'; EX3BF: 5'-TACAGTCAAAAGGCC TCTACG-3'; EX3BR: 5'-AAACAACAGCGAACTTCTCAG-3'; EX4R: 5'-CCAGAGAAACAGAGAAC-3'; EX5F: 5'-CTAATT CTTTTTCTTTCATTTTG-3'; EX5R: 5'-TGGGTGGATGTTACCC CG-3'). PCR was performed in a $20 \mu \mathrm{l}$ reaction volume with a buffer of $20 \mathrm{mM}$ Tris- $\mathrm{HCl} \mathrm{pH} 8.4,50 \mathrm{mM} \mathrm{KCl}, 1 \mathrm{mM}$ dNTPs, $1-3.5 \mathrm{mM} \mathrm{MgCl}_{2}$ (1.0 $\mathrm{mM}$ for exon 1 ; $1.5 \mathrm{mM}$ for exons $2,3 \mathrm{~A}, 3 \mathrm{~B}, 7,8,12,14 ; 3.0 \mathrm{mM}$ for exons 5, 6, 9, 11, 15; $3.5 \mathrm{mM}$ for exons 10, 16), $0.45 \mu \mathrm{M}$ each primer, $0.05 \mathrm{U}$ Taq polymerase (Platinum Taq, Invitrogen Life Technologies, USA) and $2.0 \mu \mathrm{Ci} \alpha-{ }^{33} \mathrm{P}$. Furthermore, 5\% DMSO was added to exon 1 PCR. The following cycling conditions were used:
$30 \mathrm{~s}$ at $94^{\circ} \mathrm{C}, 30 \mathrm{~s}$ at optimised annealing temperatures ranging from $51{ }^{\circ} \mathrm{C}$ to $68^{\circ} \mathrm{C}\left(51^{\circ} \mathrm{C}\right.$ for exon $8,56^{\circ} \mathrm{C}$ exon 9 , $57^{\circ} \mathrm{C}$ exon $5,58^{\circ} \mathrm{C}$ exon $4,60^{\circ} \mathrm{C}$ exon $3 \mathrm{~A}, 62^{\circ} \mathrm{C}$ exons $3 \mathrm{~B}, 6,7$, $10,64^{\circ} \mathrm{C}$ exons $11,12,14,16,65^{\circ} \mathrm{C}$ exon $15,66^{\circ} \mathrm{C}$ exon 13 , and $68^{\circ} \mathrm{C}$ exons 1,2$)$ and $45 \mathrm{~s}$ at $72^{\circ} \mathrm{C}$. Reaction products were diluted 1:1 with denaturing buffer (formamide with $0.025 \%$ xylene cyanol and $0.025 \%$ bromophenol blue) and heated to $94^{\circ} \mathrm{C}$ for $4 \mathrm{~min}$ before loading. Two sets of gel run conditions, $18 \mathrm{~h}$ at $4^{\circ} \mathrm{C}$ and $22 \mathrm{~h}$ at room temperature, were used except for exon 1 where only the room temperature run was done. Products were detected by autoradiography. For exons containing any possible band shifts the PCR was repeated. Samples were run on a $2 \%$ agarose gel and purified using a MinElute gel extraction kit (Qiagen, Valencia, CA) and eluted into a volume of $10 \mu \mathrm{l}$ according to the manufacturer's instructions. A $2 \mu \mathrm{l}$ sample of purified product was then sequenced using a Big Dye Terminator V.3 cycle sequencing kit (Applied Biosystems, Foster City, CA) in a final volume of $10 \mu \mathrm{l}$. All samples were sequenced in both directions. Cycle sequencing conditions were: initial denaturation of $96^{\circ} \mathrm{C}$ for $3 \mathrm{~min}$ followed by 25 cycles of $96^{\circ} \mathrm{C}$ for $30 \mathrm{~s}, 58^{\circ} \mathrm{C}$ for $30 \mathrm{~s}$, and $60^{\circ} \mathrm{C}$ for $2 \mathrm{~min}$. Reaction products were precipitated with ethanol/sodium acetate, washed with $70 \%$ ethanol, and resuspended in $15 \mu \mathrm{l}$ of template suppression reagent (Applied Biosystems, Foster City, CA) before loading on an ABI capillary sequencer.

\section{RT-PCR assay for IVS 1 1+5 splice site mutation}

RNA was extracted from a skin biopsy using Trizol (Invitrogen, ON, Canada). The RNA was DNAseI treated prior to being reverse transcribed. DNAseI treatment was carried out in a final volume of $10 \mu \mathrm{l}$ containing $1 \mu \mathrm{g}$ RNA $1 \times$ DNAseI buffer and $1 \mathrm{U}$ DNAseI. Samples were incubated at room temperature for $15 \mathrm{~min}, 0.5 \mu \mathrm{l}$ of $25 \mathrm{mM}$ EDTA was added, and the samples were heat inactivated at $65^{\circ} \mathrm{C}$ for $10 \mathrm{~min}$. The reverse transcription was performed in a volume of $25 \mu \mathrm{l}$ containing $\mathrm{l} \times \mathrm{MMLV}$ buffer, $8 \mathrm{mM}$ DTT, $400 \mu \mathrm{M}$ dNTP, random hexamers, and $400 \mathrm{U}$ MMLV. The samples were incubated at room temperature for $10 \mathrm{~min}$ and $37^{\circ} \mathrm{C}$ for $\mathrm{l} \mathrm{h}$ followed by heat inactivation of the reverse transcriptase at $65^{\circ} \mathrm{C}$ for $10 \mathrm{~min}$. A $1 \mu \mathrm{l}$ aliquot of reverse transcribed product was amplified in a final volume of $25 \mu \mathrm{l}$ containing

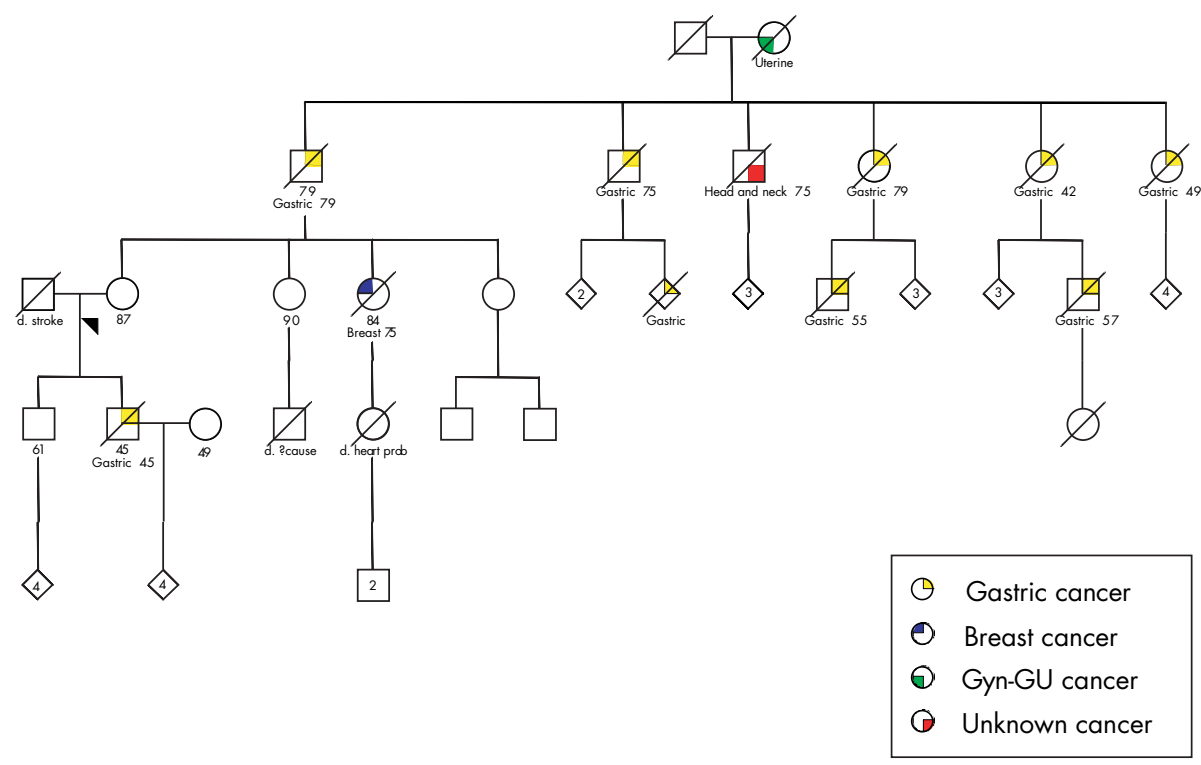

Figure 1 Family F4, showing autosomal dominant inheritance of gastric cancer with variable age of onset; the family has a mutation in the $\mathrm{CDH} 1$ gene (see table 2 and fig 2). 
$1 \times$ PCR buffer, $1.5 \mathrm{mM} \mathrm{MgCl}_{2}, 200 \mu \mathrm{M}$ dNTP, $0.5 \mu \mathrm{M}$ forward and reverse primer and $1 \mathrm{U}$ Taq polymerase (Invitrogen, ON, Canada). Cycling conditions were as follows: initial denaturation at $94^{\circ} \mathrm{C}$ for $1 \mathrm{~min}$, followed by 35 cycles of $94^{\circ} \mathrm{C}$ for $30 \mathrm{~s}, 60^{\circ} \mathrm{C}$ for $30 \mathrm{~s}$, and $72^{\circ} \mathrm{C}$ for $1 \mathrm{~min}$. Samples were run on a $2 \%$ agarose gel for visualisation. For the patient sample both bands were excised from the gel and purified using a QIAquick gel extraction kit and eluted into a $30 \mu \mathrm{l}$ volume. A $1.5 \mu \mathrm{l}$ aliquot of purified product was then sequenced using a Big Dye Terminator V.3 cycle sequencing kit (Applied Biosystems, Foster City, CA) in a final volume of $10 \mu$. Cycle sequencing conditions were: initial denaturation of $96^{\circ} \mathrm{C}$ for $3 \mathrm{~min}$ followed by 25 cycles of $96^{\circ} \mathrm{C}$ for $30 \mathrm{~s}, 55^{\circ} \mathrm{C}$ for $30 \mathrm{~s}$, and $60^{\circ} \mathrm{C}$ for $2 \mathrm{~min}$. Reaction products were precipitated with ethanol/sodium acetate, washed with $70 \%$ ethanol, and resuspended in $15 \mu \mathrm{l}$ of template suppression reagent (Applied Biosystems, ON, Canada) before loading on an ABI capillary sequencer.

\section{Functional assessment of missense variants} Construction of the plasmids encoding wild type and mutant E-cadherins

CHO-Kl (Chinese hamster ovary) cells stably expressing the E-cadherin cDNA mutants were established by electroporation as previously described..$^{18}{ }^{19}$ Briefly, mutant plasmids were obtained by nested PCR using specific primers using wild type E-cadherin cloned in pcDNA3 as DNA template (G2195A: For 5'-CTGTTTCTTCAGAGGAGAGCG-3', Rev 5'CGCTCTCCTCTGAAGAAACAG-3'; T1225C: For 5'-AATACCC CAGCGCGGGAGG-3', Rev 5'-CCTCCCGCGCTGGGGTATT-3'; G892A: For 5'-ACAATACCGCCATCGCTTAC-3', Rev 5'GATGGCGGTATTGTAGGTGT-3'). After transfection, cells were grown at $37^{\circ} \mathrm{C}$ under $5 \% \mathrm{CO}_{2}$ in humidified air, in a-MEM (+) medium (Gibco BRL) supplemented with 5\% foetal bovine serum, $2 \mathrm{mM}$ L-glutamine, $1 \%$ penicillin/ streptomycin, and $1 \mathrm{mg} / \mathrm{ml}$ geneticin. Single cell clones were selected and analysed for E-cadherin expression by Western blotting, using the human E-cadherin monoclonal antibody HECDI (R\&D System, 1/3500 dilution) for protein staining.
At least two independent clones for each cell line were used in each experiment, to exclude clonal dependence of the results.

\section{Cell aggregation assay}

As previously reported, ${ }^{18}{ }^{19}$ the ability of cells to aggregate was characterised in a fast aggregation assay. Briefly, single cell suspensions of transfected cells were incubated in an isotonic buffer containing $1.25 \mathrm{mM} \mathrm{Ca}{ }^{2+}$. Particle diameters were measured at the start $\left(\mathrm{T}_{0}\right)$ and after $30 \mathrm{~min}\left(\mathrm{~T}_{30}\right)$, using an LS200 particle size counter (Coulter Electronics). Results were plotted against the percentage of volume distribution. The E-cadherin-blocking antibody MB2 (1/20 dilution) was used as a control for inhibition of aggregation.

\section{Collagen invasion assay}

The invasion assay was performed as previously described. ${ }^{18} 19$ Briefly, collagen gels with a minimum thickness of $250 \mathrm{~mm}$, were prepared in a 6 well plate (Nunc International, Rochester, NY), from a collagen type I solution (Upstate Biotechnology, Lake Placid, NY), and polymerised overnight at $37^{\circ} \mathrm{C}$. Mutant E-cadherin expressing cells $\left(1 \times 10^{5}\right)$ were incubated on top of the collagen gels, for $24 \mathrm{~h}$ at $37^{\circ} \mathrm{C}$ and invasion indices (\%) expressed as ratios between the number of invasive cells inside the gel and the total number of cells, counted in at least 12 microscopic fields.

\section{RESULTS}

\section{Variant detection sequencing of the $\mathrm{CDH} 1$ gene}

Ten loss-of-function mutations including two insertions, five deletions, two splice site substitutions, and one complex deletion/insertion involving a splice site were seen in 10 different families (table 2). Three missense mutations were also identified (table 2). Their functional consequences are described below. All mutation carriers found were heterozygous for a specific mutation, consistent with the autosomal dominant inheritance of HDGC in these families. No two families had the same mutation. All mutations seen were novel (not seen before). Of the three mutations involving

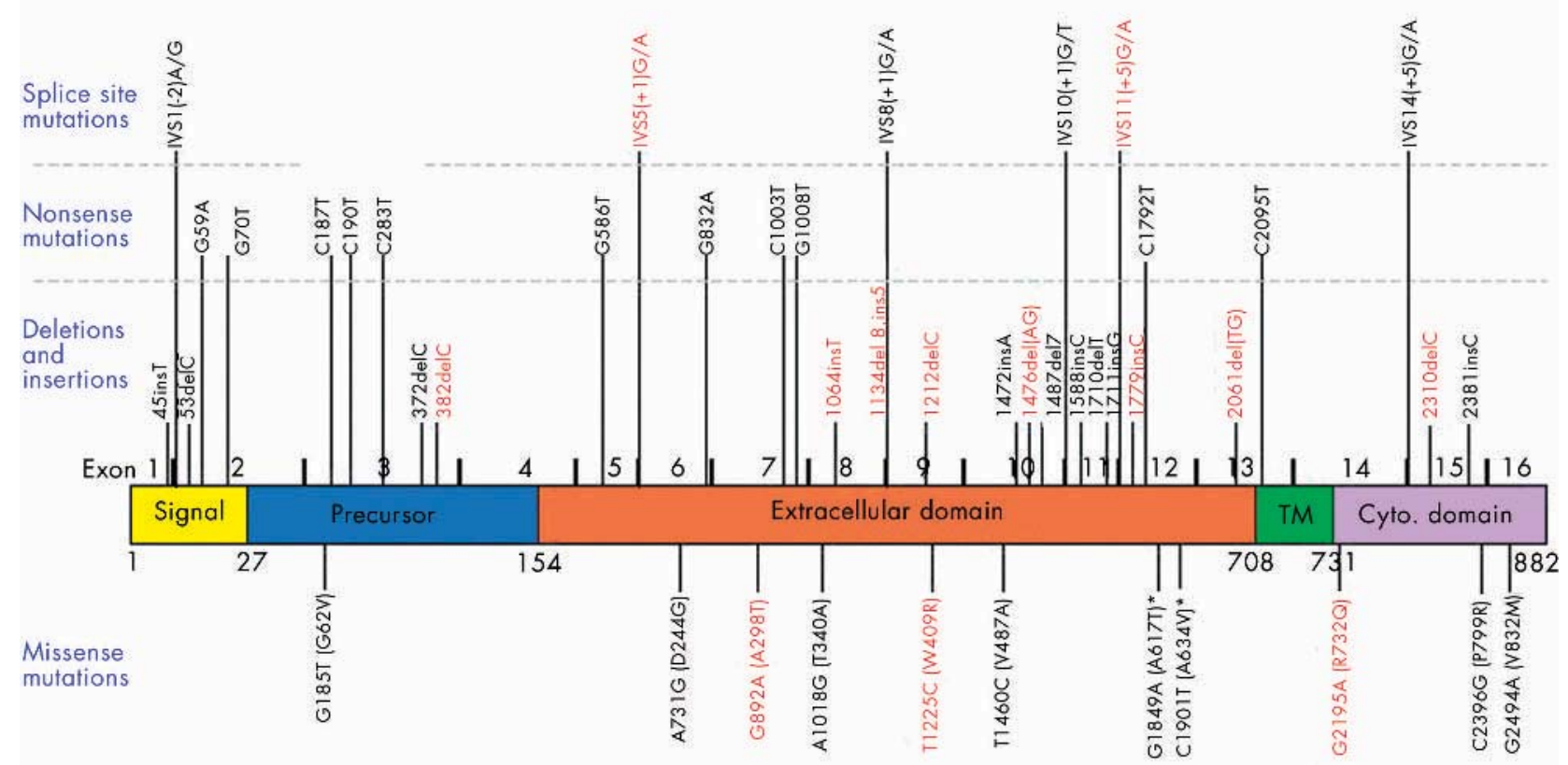

Figure $2 \mathrm{CDH} 1$ mutations found to date. Truncating and splice site mutations are found above the schema, missense mutations below it. Mutations found in the present study are indicated in red. Those marked with an asterisk have also been reported as somatic mutations in sporadic DGC. Polymorphisms are not shown. 
A

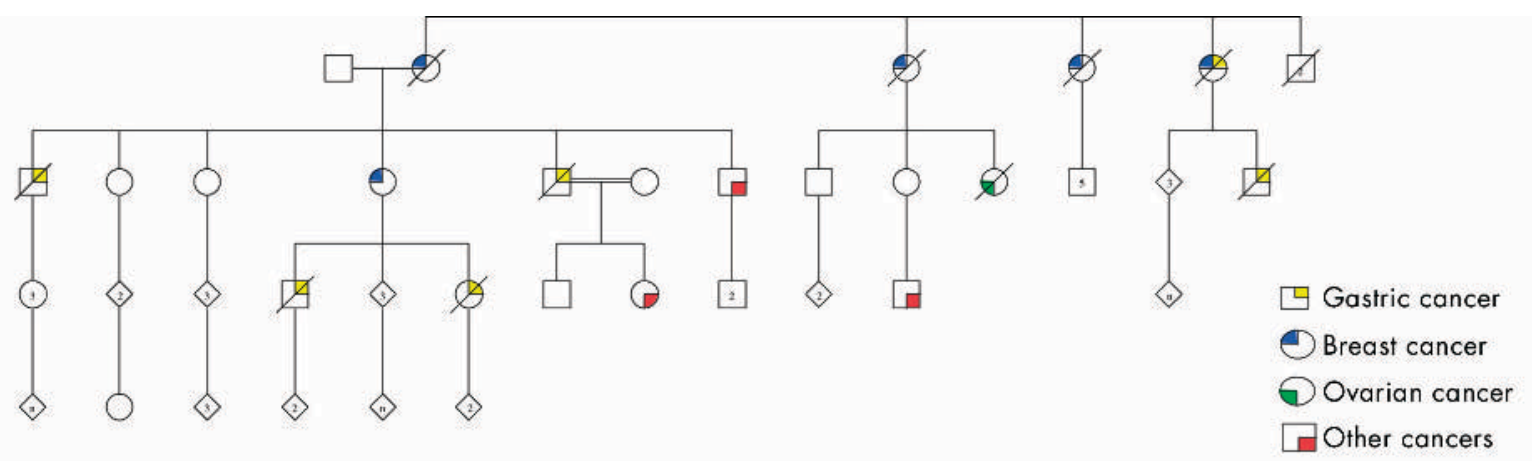

B

Normal

A G A CA A T G G T A A G G G G G C C T CA T C
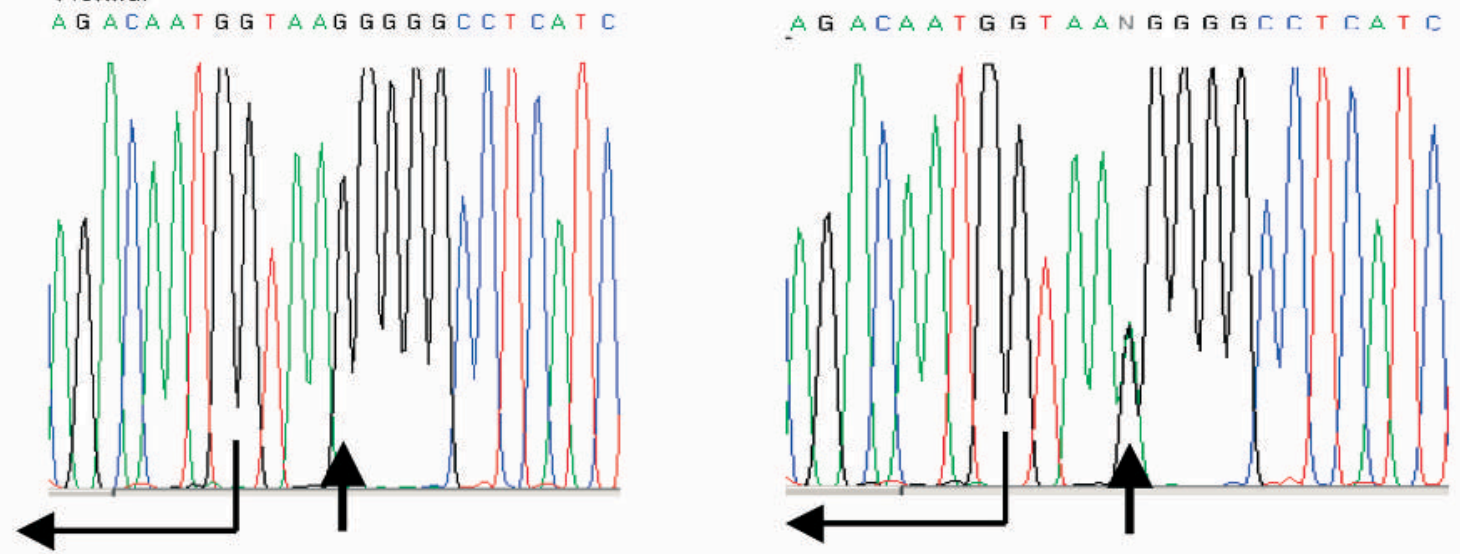

Exon 11

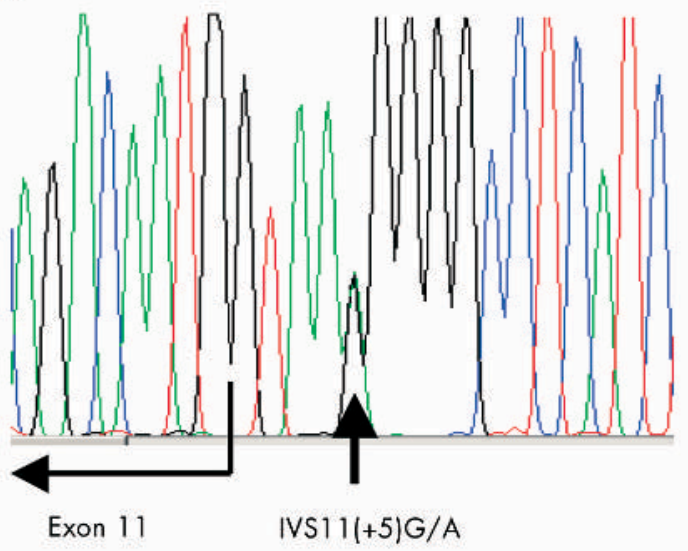

C
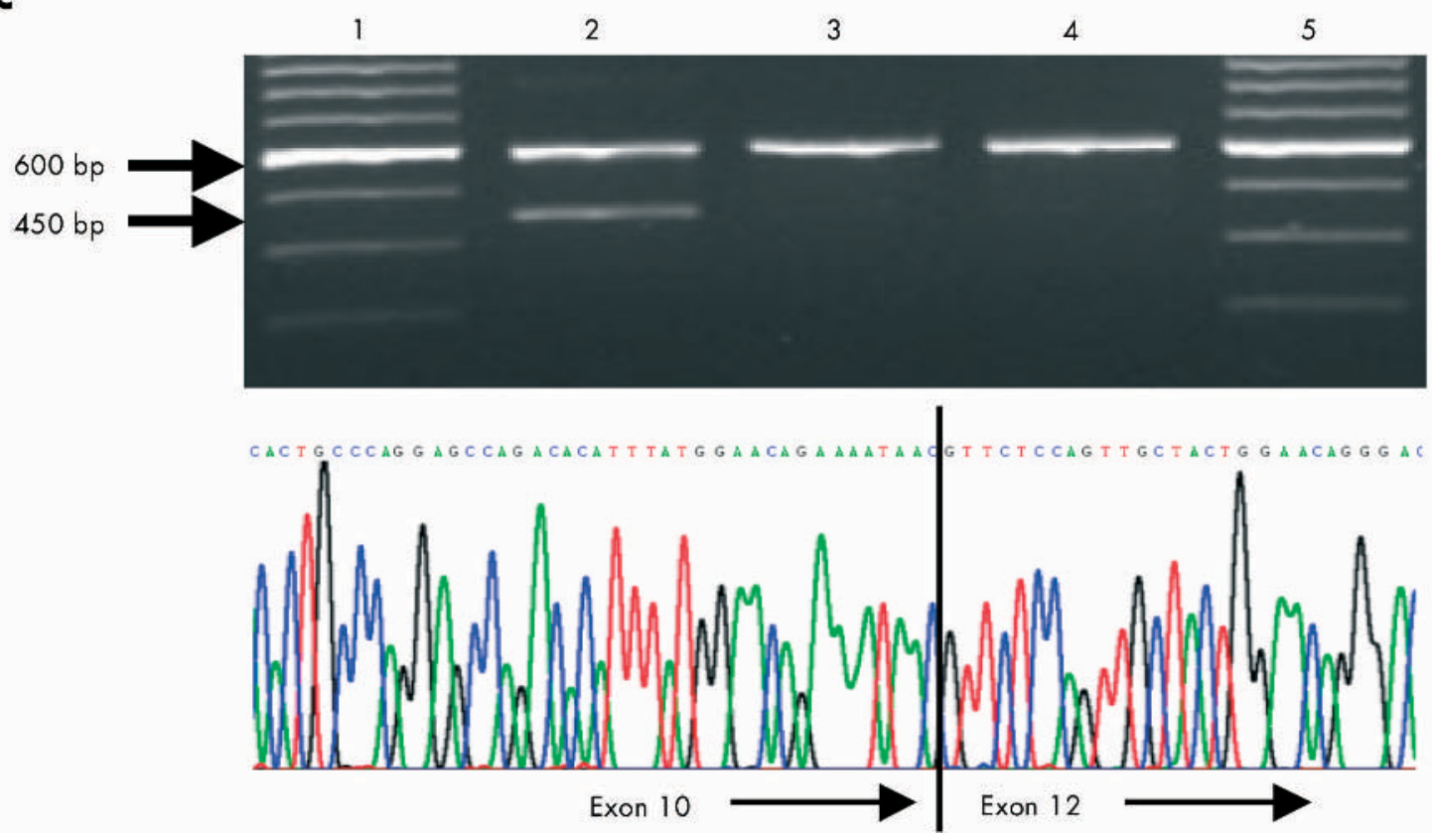

Figure 3 (A) Family F1 1. (B) Sequencing of genomic DNA. Arrow indicates location of $G$ to A substitution. (C) Results of RT-PCR. Lane 2 shows both the normal band (upper band) and the band with deletion of exon 11. Lanes 3 and 4 show the RT-PCR from normal control samples. Sequencing chromatogram confirms complete loss of exon 11. 
splice sites, the one in family Fl was a G to A substitution of the highly conserved $(+1)$ position of the splice donor site of IVS5, a substitution almost certain to have functional consequences for the splicing of that intron, and likely to lead to in-frame deletion of exon 5 from the transcript. Consistent with this predicted effect being deleterious for the function of E-cadherin, an exon 5 deletion has previously been described as a somatic $\mathrm{CDHl}$ mutation in invasive lobular breast cancer. ${ }^{20}$ The second splice site mutation was a $G$ to A substitution at the $(+5)$ position of IVS11 in family F11 (fig 2). This mutation leads to the deletion of exon 11 from the CDHl transcript as demonstrated by RT-PCR (fig 3). The third splice site variant involved a deletion of the exon 8/ intron 8 splice boundary and would be expected to have an adverse functional effect. All the mutation positive families were of Northern European descent except for family F10 (Italian) and family F42 (Spanish). All the mutations in this study have been deposited into the database, dbSNP (http:// www.ncbi.nlm.nih.gov/SNP/).
A total of 29 DGC families were identified that did not have $\mathrm{CDH} 1$ mutations within their protein-coding exons. Germline deletion of the entire CDHl gene can be excluded for 23/29 of these families by the presence of heterozygosity for polymorphisms within $\mathrm{CDHl}$ exons or in flanking intronic sequences. Deletion of single whole exons of CDHl cannot be ruled out by this screening method; however, this mechanism is unlikely to account for all of the 29 families studied that did not show CDHl mutations.

\section{Functional assays of missense mutations}

Sorting Intolerant from Tolerant (SIFT) ${ }^{21}$ uses evolutionary conservation to predict the impact of amino acid substitutions on protein function. SIFT analysis predicted that all three missense mutations identified in DGC families affect conserved residues and would be expected to have deleterious effects on protein function. Residue W409 and R732 are conserved in human, mouse, rat, Xenopus, and zebrafish, implying an important function. W409 is found in the third

Table 2 Details of the gastric cancer families in the study and mutations detected

\begin{tabular}{|c|c|c|c|c|c|c|}
\hline $\begin{array}{l}\text { Family } \\
\text { no }\end{array}$ & Cancer type, age & $\begin{array}{l}\text { Study criteria } \\
\text { met }\end{array}$ & $\begin{array}{l}\text { Other family members with } \\
\text { gastric cancers, } n \text { (ages) }\end{array}$ & $\begin{array}{l}\text { Family members with } \\
\text { breast cancer, } \mathrm{n} \text { (confirmed } \\
\text { lobular breast cancer) }\end{array}$ & $\begin{array}{l}\text { CDH1 mutation: } \\
\text { exon, nucleotide } \\
\text { (amino acid) }\end{array}$ & Type of mutation \\
\hline $\mathrm{F} 1$ & DGC, 40 & IA & $3(36,48,50)$ & 1 & IVS5(+1) G>A & Splice site \\
\hline F2 & DGC, 33 & 1 & $2 \dagger(35,42)$ & 0 & Exon 12,1779 ins $C$ & Insertion \\
\hline F3 & DGC, 9 & iA & $1(40)$ & 0 & Negative & \\
\hline F4 & Unaffected & IA & $\begin{array}{l}8(42,45,49,57,75,79,79, \\
\text { unknown) }\end{array}$ & 1 & Exon 15, 2310delC & Deletion \\
\hline F5 & Colon, 74 & 1 & $4(25 \uparrow, 42 \uparrow, 50$, unknown $)$ & 3 & Negative & \\
\hline F6 & DGC, 45 & 5 & 0 & $3(1)$ & Negative & \\
\hline F7 & DGC, 51 & $6^{*}$ & 0 & 0 & $\begin{array}{l}\text { Exon 9, T1226C } \\
\text { (W409R) }\end{array}$ & Missense \\
\hline F8 & DGC, 62 & $2 \mathrm{~A}$ & $3(58, \sim 60,63)$ & 0 & Negative & \\
\hline F9 & DGC, 61 & 1 & $4(17,32 \dagger, 46 \dagger, 47 \dagger)$ & 4 & Exon 9, 1212 delC & Deletion \\
\hline F10 & DGC, 32 & $1 \mathrm{~A}$ & $6(40,42,45,50,55,56)$ & 2 & Exon 3, 382delC & Deletion \\
\hline F11 & DGC 48 & 1 & $2(44 t, 44 t)$ & $5(1)$ & IVS11(+5) G>A & Splice site \\
\hline $\mathrm{F} 12$ & DGC, 31 & 3 & 0 & 0 & Negative & \\
\hline F13 & $\begin{array}{l}\text { Unaffected (colonic } \\
\text { polyp) }\end{array}$ & 1 & $2(36+, 70+)$ & $4(2)$ & $\begin{array}{l}\text { Exon 14, G2195A } \\
\text { (R732Q) }\end{array}$ & Missense \\
\hline F14 & DGC, 65 & $2 \mathrm{~A}$ & $2(44,70)$ & 0 & Negative & \\
\hline F15 & $\begin{array}{l}\text { Bilateral lobular } \\
\text { breast cancer, } 52\end{array}$ & 5 & $1(40 \dagger)$ & 1 & Negative & \\
\hline F16 & DGC, 24 & 1 & $1 \dagger(47)$ & 0 & $\begin{array}{l}\text { Exon 13, 2061del } \\
\text { (TG) }\end{array}$ & Deletion \\
\hline F17 & Prostate, 72 & $1 \mathrm{~A}$ & $5(30,37 \dagger, 39 \ddagger, 50,70)$ & 0 & Negative & \\
\hline F18 & DGC, 32 & $1 \mathrm{~A}$ & $1(40)$ & 0 & $\begin{array}{l}\text { Exon } 10,1476 \mathrm{del} \\
\text { (AG) }\end{array}$ & Deletion \\
\hline F19 & DGC, 74 & 3 & 0 & $3(2)$ & Negative by SSCP & \\
\hline $\mathrm{F} 20$ & DGC, 75 & $2 \mathrm{~A}$ & $2(55 ; 72)$ & 0 & Negative by SSCP & \\
\hline F21 & DGC, 58 & $2 \mathrm{~A}$ & $1(59)$ & 0 & Negative & \\
\hline F22 & GC, 61 & 7 & $6(54 \ddagger ; 59 ; 74 ; 3$ in $70 \mathrm{~s})$ & 2 & Negative & \\
\hline F23 & Unaffected & $1 \mathrm{~A}$ & $2(42 \dagger ; 60 s)$ & 2 & Negative & \\
\hline F24 & Oesophageal, 62 & IA & $3(\sim 50,63,65)$ & 0 & Negative & \\
\hline $\mathrm{F} 25$ & DGC, 34 & 1 & $2(50,58+)$ & 0 & Exon 8, 1064insT & Insertion \\
\hline F26 & DGC, 36 & 1 & $2(32+, 33)$ & 0 & $\begin{array}{l}\text { Exon 7, G892A } \\
\text { (A298T) }\end{array}$ & Missense \\
\hline F27 & DGC, $<50$ & 3 & 0 & 0 & Negative & \\
\hline $\mathrm{F} 28$ & DGC, 43 & $1 \mathrm{~A}$ & $1(60)$ & 0 & Negative & \\
\hline F29 & DGC, $<50$ & 3 & 0 & 0 & Negative & \\
\hline F30 & DGC, 55 & 1 & $3(44 \dagger, 52 \uparrow$, unknown) & 2 & Negative & \\
\hline F31 & DGC, $<50$ & 3 & 0 & 0 & Negative & \\
\hline F32 & DGC, 45 & 3 & 0 & 0 & Negative & \\
\hline F33 & DGC, 48 & 3 & 0 & 0 & Negative & \\
\hline F34 & DGC, 33 & 1 & 2 (35t, unknown) & 0 & Negative & \\
\hline F35 & Oesophageal, 60 & 1 & $3(34 \uparrow, 44 \uparrow, 68)$ & 0 & Negative & \\
\hline F36 & $\mathrm{GC} \uparrow, 46$ & IA & 1 (unknown) & 0 & Negative & \\
\hline F37 & DGC, 36 & 3 & 0 & 0 & Negative & \\
\hline F38 & DGC, 39 & 1 & $3+(33,67,69)$ & 0 & Negative & \\
\hline F39 & DGC, 48 & 3 & 0 & 0 & Negative & \\
\hline F40 & DGC, 38 & 1 & $1(54)$ & 0 & Negative & \\
\hline F41 & DGC, 27 & 1 & 3 (30†; 32†; unknown) & 0 & $\begin{array}{l}\text { Exon } 8,1134 \text { del8, } \\
\text { ins5 }\end{array}$ & $\begin{array}{l}\text { Deletion and } \\
\text { insertion }\end{array}$ \\
\hline F42 & DGC, 41 & 1 & $2(44 \dagger, 57)$ & 0 & Negative & \\
\hline $\mathrm{F} 43$ & DGC,$<50$ & 3 & 0 & 0 & Negative & \\
\hline
\end{tabular}


Table 3 Primer sequences used in the study and their annealing temperatures

\begin{tabular}{|c|c|c|c|}
\hline Exon & Forward $5^{\prime}-3^{\prime}$ & Reverse $5^{\prime}-3^{\prime}$ & $T_{m}\left({ }^{\circ}\right)$ \\
\hline 1 & M13F GTGAACCCTCAGCCAATCAG & M13R TGACGACGGGAGAGGAAG & 63 \\
\hline 2 & M13F TGTTGGTTCGGTGAGCAG & M13R GGTGTGGGAGTGCAATTTCT & 61 \\
\hline 3 & M13F CGCTCTTTGGAGAAGGAATG & M13R AACGGTACCAAGGCTGAGAA & 58 \\
\hline 4 & M13F GCTGTCTGGCTAGGITGGAC & M13R TाTCCCTTTCTCTCCTTGG & 58 \\
\hline 5 & MI3F GAAAGGGAAAAGACCCAGTG & M13R GGATCCAGCATGGGTTGAC & 58 \\
\hline 6 & M13F GCCCCTTCTCCCATGTTा & MI3R CTTGGGGCTTGGACAACACT & 56 \\
\hline 7 & MI3F GGGCAGAATTGGATTAAGCA & M13R TGTCCACGGGATTGAGCTA & 57 \\
\hline 8 & M13F CTGGGCTAGGCCAAAGGT & M13R CCATGAGCAGTGGTGACACTT & 57 \\
\hline 9 & MI3F AATCCTTTAGCCCCCTGAGA & M13R AGGGGACAAGGGTATGAACA & 61 \\
\hline 10 & M13F CCAAAAGCAACAGTTAAGGA & M13R CAAATGACAAAATGCCATGA & 56 \\
\hline 11 & M13F AGCGCTTAAGCCGITICA & M13R GAGGGGCAAGGAACTGAACT & 60 \\
\hline 12 & MI3F AAGGCAATGGGGATCATTA & M13R ATTGAAAGGTGGGGATCTGG & 59 \\
\hline 13 & M13F CAATTTTATTCTGGAATGAGCTTTT & M13R CAGGAAATAAACCTCCTCCATTT & 55 \\
\hline 14 & M13F GCTGCTTCTGGCCTTCTTTA & MI3R GCTGTTTCAAATGCCTACCTCT & 55 \\
\hline 15 & M13F TGAACATAGCCCTGTGTGTATG & MI3R ITITGGACACAACTCCTCCTG & 58 \\
\hline 16 & MI3F AGACTTCTTGCCCCAGATGA & M13R AACCACCAGCAACGTGATTT & 63 \\
\hline
\end{tabular}

calcium binding domain of the E-cadherin protein; R732 is located at the intracellular border of the cytoplasmic domain of the molecule. Residue A298 is in the second calcium binding domain of the molecule and is conserved in all these species but Xenopus, which contains a conservative substitution of glycine for the alanine residue.

To confirm the theoretical prediction of a deleterious effect on protein function for the three identified E-cadherin germline missense mutations, functional assays including cell-cell adhesion and collagen invasion have been performed in vitro. CHO E-cadherin negative cells with epithelial origin have been used as cell model system and transfected to stably express the different E-cadherin germline mutations. To exclude clonal dependence of the results, at least two independent clones for each mutation have been used for the functional analysis; results have been discussed in comparison to what was observed for cells expressing the wild type protein. For the study, only clones expressing an equal amount of protein upon transfection were selected using quantitative Western blot analysis. All three mutants resulted in the expected $120 \mathrm{kDa}$ band. Results for the functional characterisation are reported in table 4. All mutations dramatically affect the ability of E-cadherin to mediate cell-cell adhesion and suppress cell invasion, supporting their pathogenic role in gastric cancer.

\section{Family ascertainment criteria and $\mathrm{CDH} 1$ screening}

To determine the optimal inclusion criteria for families for $\mathrm{CDH} l$ diagnostic screening, we assessed six different criteria for ascertainment of families and determined which ones identify families likely to benefit from CDHl screening. Eight of the 15 (53\%) families who meet criterion 1 (two or more documented cases of DGC in first degree relatives, with at least one diagnosed before age 50) had a CDHl mutation; four of the $10(40 \%)$ families who met our revised criterion IA (two or more cases of GC, with at least one documented DGC diagnosed before the age of 50) and one family that met criterion 6 (one family member diagnosed with DGC and another with colon cancer) carried CDHl mutations (table 1). The single family that met criterion 6 had a family member with a signet ring carcinoma of the colon, a cancer known to be associated with somatic loss of E-cadherin expression. ${ }^{22}$ The optimal criteria for $\mathrm{CDHl}$ diagnostic screening, as determined in the present study, are fulfilment of criterion 1 , or the less stringent criterion 1A. Insufficient families met criterion 2, so assessment of this criterion as a means of identifying families for $\mathrm{CDHl}$ diagnostic screening could not be addressed using this sample set. No mutations were identified in the family (F22) that, upon pathologic review, was demonstrated to have intestinal type gastric cancer.

Twelve of the 42 DGC families included women with breast cancers. Within the 25 families who met criteria 1 or lA there were 17 women with breast cancer; of these three had confirmed lobular breast cancer and one ductal adenocarcinoma: the pathologic subtype of the other breast cancers is unknown. Within these 25 families there were 128 women who were either sisters or mothers of individuals with gastric cancer or sisters or mothers of obligate carriers for gastric cancer susceptibility. In the 12 criteria 1 or $1 \mathrm{~A}$ families in whom a $\mathrm{CDHl}$ mutation was identified, 12 breast cancers occurred amongst 75 at risk females only half of whom would be expected to carry mutations. These 12 breast cancers occurred in five CDHl mutation positive families with five cases concentrated in family F1l (fig 2). Although insufficient genotyping and pathological data for a formal penetrance study are available, our results appear concordant with the previous calculated breast cancer risk of 39\% in germline $\mathrm{CDH} 1$ mutation carriers. The five $\mathrm{CDHl}$ mutations from the families with HDGC and breast cancers were distributed across the gene suggesting that no genotypephenotype correlation is present.

\section{DISCUSSION}

A role for E-cadherin in tumour development is now well established, ${ }^{23}$ since many human carcinomas such as skin, head and neck, lung, breast, thyroid, gastric, colon, and ovarian exhibit reduced E-cadherin expression relative to their normal cellular counterparts. Somatic loss of E-cadherin expression is seen in most diffuse gastric cancers and in lobular breast cancers, although expression is usually maintained in intestinal gastric cancers and ductal breast cancers. ${ }^{10} 2425$

In sporadic diffuse gastric cancers and lobular breast cancers, E-cadherin loss is associated with somatic point mutations of the E-cadherin gene, loss of heterozygosity, and/ or promoter hypermethylation. ${ }^{10} 122226$ The sequence of these events is unknown. In most carcinomas loss of E-cadherin is usually a late event associated with invasion and metastasis. In hereditary diffuse gastric cancers, however, E-cadherin loss is likely to be an early, and potentially an initiating event.

The genetic attributable risk for gastric cancer development is similar to that for breast and colorectal cancers. ${ }^{27}$ As with these other cancers, there are families demonstrating autosomal dominant inheritance and also those that show clustering of gastric cancers for which the etiology is likely multifactorial. ${ }^{27}$ Family history is a positive risk factor for 
Table 4 Functional characterisation of missense mutations

\begin{tabular}{|c|c|c|c|}
\hline & \multicolumn{2}{|l|}{ Aggregation } & \multirow{2}{*}{$\begin{array}{l}\text { Invasion } \\
\text { Invasion index (\%) }\end{array}$} \\
\hline & Particle diameter $(\mu \mathrm{m}) \mathrm{T}_{0}$ & Particle diameter $(\mu \mathrm{m}) \mathrm{T}_{30}$ & \\
\hline Mock cells* & 16.52 & 19.25 & $10.8 \pm 1.2$ \\
\hline Wild type & 17.95 & 1067.00 & $1.2 \pm 0.2$ \\
\hline A298T & 21.60 & 26.21 & $13.5 \pm 0.8$ \\
\hline W409R & 20.00 & 32.21 & $22.05 \pm 0.7$ \\
\hline R732Q & 22.08 & 29.22 & $13.2 \pm 1.1$ \\
\hline
\end{tabular}

both diffuse and intestinal gastric cancers. ${ }^{7}$ The heritable factors that account for the increased risk in families of index cases include both highly penetrant mutations as well as polymorphisms that may modify host-environment interactions. ${ }^{27} 28$ Autosomal dominant gastric cancer is both clinically and genetically heterogeneous. Most families show only diffuse cancers. ${ }^{7}$ Gastric carcinomas are seen in families with germline p53 mutations, ${ }^{29}$ and hereditary non-polyposis colon cancer (HNPCC).$^{29}$ However, $85 \%$ of HNPCC associated gastric cancers are of the intestinal type. ${ }^{30} 31$ Gastric cancer is also seen in both Peutz-Jeghers syndrome (PJS) and familial adenomatous polyposis (FAP). In PJS, hamartomatous polyps in the stomach occur in approximately $24 \%$ of patients. ${ }^{32}{ }^{33}$ However, the risk of gastric cancer is small. Although gastric adenomatous polyps occur in about $10 \%$ of individuals with FAP, the risk of gastric cancer is small. ${ }^{33-35}$

In 1998, Parry Guilford and colleagues described germline truncating E-cadherin mutations in three Maori families with autosomal dominant diffuse gastric cancer. ${ }^{8}$ Soon afterward, we reported similar mutations in three families of Northern European origin. ${ }^{9}$ E-cadherin acts as a tumour suppressor gene in these families, with the loss of expression of the wild type E-cadherin allele usually occurring through promoter hypermethylation. ${ }^{26}$ To date, including this study, 27 truncating E-cadherin mutations have been reported, only one of which has been found twice. ${ }^{90}{ }^{16-42}$ These mutations are present in approximately one third of families with two or more first degree relatives having confirmed cases of diffuse gastric cancer. ${ }^{7}$ A penetrance analysis of E-cadherin mutations in 11 families showed an estimated cumulative risk of gastric cancer by age 80 years of $67 \%$ for men $(95 \%$ confidence interval (95\% CI) 39 to 99 ) and $83 \%$ for women (95\% CI 58 to 99$).{ }^{43}$

We have screened a series of 42 DGC families for germline mutations in the CDHI gene. Thirteen families (31\% overall) had either overt loss of function mutations or missense mutations likely to have functional consequences for the E-cadherin protein. Functional assays have demonstrated that all missense mutations do not retain the wild type E-cadherin functions of cell adhesion and suppression of invasion. All of the CDHl mutations observed in these families are novel, underlining the absence of founder effect previously noted for $\mathrm{CDHl}$ mutations underlying this familial cancer. ${ }^{10}$

When a detailed comparison of $\mathrm{CDHl}$ mutation status $v$ family ascertainment criteria is performed it is apparent, however, that families that have $\mathrm{CDHl}$ mutations are those with a strong family history of early onset diffuse gastric cancer. Some $48 \%$ of such families had germline CDHI mutations in this study. The nature of the families in this sample set makes it difficult to determine whether a strong family history alone (in the absence of early onset disease; criterion 2) also correlates with the presence of $\mathrm{CDHl}$ mutations. The only family (F7) with an E-cadherin mutation (W409R) that does not meet criteria lor $1 \mathrm{~A}$, included an individual with a histologically defined signet ring cell cancer of the colon (SRCC). We have previously observed an SRCC in a 35 year old male with another CDH1 missense mutation (Thr340Ala). ${ }^{10}$ Signet ring carcinomas of the colon are extremely rare, representing nine of 3000 $(0.003 \%)$ of colon cancers in a series of colon cancers from Singapore, ${ }^{44} 27$ of $2589(0.01 \%)$ cases from Canada, ${ }^{45}$ and 24 of $323(7 \%)$ colon cancer from the USA. ${ }^{46}$ The higher proportion of signet ring carcinomas in the latter study reflect that this study cohort was derived from a clinical trial versus being population based. Although up to $50 \%$ of SRCCs have microsatellite instability, a feature associated with HNPCC, little is known about the pathogenesis of microsatellite stable cases other than loss of E-cadherin expression. $^{22}{ }^{46}$ The occurrence of this rare subtype of colon cancer in two CDHl mutation positive families is insufficient to prove an association. However, given the known role of loss of somatic E-cadherin expression in SRCCs and the reported presence of intramucosal signet ring carcinoma, a lesion previously described in the prophylactic gastrectomy specimens of germline $\mathrm{CDHl}$ mutation carriers, a role for CDHl germline mutation in the susceptibility to SRCC is feasible ${ }^{45}$ and warrants further investigation.

Our study and others ${ }^{5}{ }^{18}$ show that a single individual with early onset DGC without a strong family history is unlikely to carry a $\mathrm{CDHl}$ germline mutation. Our current data set does not contain enough families with both lobular breast cancer and DGC to determine if CDHl screening is advisable for such families.

Breast cancer was reported in the first E-cadherin associated HDGC families, ${ }^{8}$ but the histologic type was not determined. Keller ${ }^{6}$ reported a family in which a germline truncating mutation carrier had a lobular breast cancer. In sporadic lobular breast cancers, loss of E-cadherin expression is commonly seen and somatic mutations are frequently seen in combination with loss of heterozygosity at the E-cadherin locus. In the 11 families included in the IGCLC penetrance study, ${ }^{40}$ nine cases of breast cancer were reported. For women, the cumulative risk of breast cancer was 39\% (95\% CI 12 to 84). Lobular cancer was present in all five cases where pathology was available. No CDHl mutations were identified in the germline DNA of 65 women with lobular breast carcinoma in situ (LCIS), ${ }^{47}$ six families with both breast and gastric cancers, ${ }^{47}$ or in 13 patients with familial lobular breast cancer. ${ }^{24}$ In this study, 17 cases of breast cancer occurred in families with germline E-cadherin mutations. However, only $4 / 17$ cases of the breast cancers could be confirmed pathologically. Of these, three were the lobular type. These data are supportive but insufficient to conclusively prove an association between lobular breast cancer and germline E-cadherin mutations. Since breast cancers were also seen in the CDHl negative families it is possible that the cancer susceptibility in these families may be caused by $\mathrm{CDHl}$ mutations missed by bi-directional sequencing or mutation events in genes that, like $\mathrm{CDH}$, have relevance for both DGC and LBC.

These results are key for the development of optimal guidelines for the management of individuals within HDGC families. At present, the best preventive treatment for HDGC 
is prophylactic gastrectomy, a procedure that is life saving but has an associated high morbidity and mortality rate. The importance of identifying the genetic basis of cancer susceptibility in HDGC families has been underscored by the recent observation of early gastric cancers in 10 prophylactic gastrectomy samples from germline E-cadherin mutation carriers. ${ }^{48}{ }^{49}$ The findings suggest that prophylactic gastrectomy is currently the best treatment for germline mutation carriers and that current endoscopic screening techniques are inadequate. In 50-70\% of HDGC families, cancer susceptibility is caused by unknown genetic factors and so predictive testing is not possible at present. Missense mutations remain problematic for clinical management because, without both extensive family data and functional data, it is difficult to predict the pathogenicity of a missense mutation. In the absence of such data, it may not be appropriate to use E-cadherin missense mutation status to segregate risk within an HDGC family.

A total of 29 families were found not to have a mutation in the coding region of the E-cadherin gene. These families could carry a $\mathrm{CDHl}$ mutation for which our assay is insensitive, such as a small intragenic deletion involving one or more exons. However, it may be more likely that most of these families bear mutations in other HDGC susceptibility genes that remain to be discovered. This view is consistent with previous observations of genetic ${ }^{5051}$ and linkage ${ }^{36}$ heterogeneity in this disease. Unfortunately only a minority of these families are of adequate size to permit linkage mapping. Identification of novel genes that underlie HDGC will therefore rely on combination strategies that employ candidate gene screening, perhaps in combination with linkage mapping in those few families of sufficient size. The $29 \mathrm{CDHl}$ mutation negative families identified in this study represent a resource for the identification of novel HDGC genes. Identification of such genes will substantially improve the diagnostic opportunities for at risk individuals in such families, in addition to providing information about the biochemical pathways that underlie this disease.

In conclusion, germline $\mathrm{CDHl}$ mutations are present in close to $50 \%$ of families in which there is both a documented DGC in an individual diagnosed at age 50 or younger and a family history of gastric cancer. Testing individuals who do not meet these criteria is unlikely to yield $\mathrm{CDHl}$ mutations.

\section{ACKNOWLEDGEMENTS}

We are very grateful to the families who participated in this study. This work was supported by Genome Canada and Genome British Columbia. David Huntsman is the recipient of a Michael Smith Foundation for Health Research Career Investigator Award.

\section{Authors' affiliations}

A R Brooks-Wilson, S Leach, Y S N Butterfield, J Jeyes, J Schinas, Genome Sciences Centre, British Columbia Cancer Agency, 600 W. 10th Avenue, Vancouver, BC, Canada V5Z 4E6

A R Brooks-Wilson, B MacGillivray, Department of Medical Genetics, University of British Columbia, Vancouver, BC, Canada V6H 3N1

P Kaurah, M Kelsey, B MacGillivray, D Huntsman, Hereditary Cancer Program, British Columbia Cancer Agency, Vancouver, BC, Canada V5Z 4E6

G Suriano, P Ferreira, M J Oliveira, R Seruca, Instituto de Patologia e Imunologia Molecular da Universidade do Porto (IPATIMUP), 4200 Porto, Portugal

J Senz, Prostate Centre, Vancouver General Hospital, Vancouver, BC, Canada V6H $3 Z 6$

N Grehan, Department of Oncology, University of Cambridge and Wellcome Trust Centre for Molecular Mechanisms in Disease/ Cambridge Institute for Medical Research, Wellcome Trust/MRC Building Level 6, Cambridge CB2 2XY, UK

J Bacani, Samuel Lunenfeld Research Institute, University of Toronto, Toronto, ON, Canada M5G IX5
P MacLeod, M Micek, Medical Genetics, Victoria General Hospital, Victoria, BC, Canada V8Z 6R5

J Ford, Divisions of Oncology and Medical Genetics, Stanford University Medical Centre, Stanford, CA 94305, USA

W Foulkes, Program in Cancer Genetics, Departments of Oncology and Human Genetics, McGill University, Montreal, QC, Canada H3G 1A4 K Australie, Division of Medical Genetics, McGill University, Montreal, QC, Canada H3G 1A4

C Greenberg, M LaPointe, Section of Genetics and Metabolism, Children's Hospital, Winnipeg, MB, Canada R3A 1R9

C Gilpin, S Nikkel, Department of Genetics, Children's Hospital of Eastern Ontario, Ottawa, ON, Canada K1H 8L1

D Gilchrist, Medical Genetics Clinic, University of Alberta, Edmonton, AB, Canada T6G 2R7

R Hughes, Departments of Oncology and Medical Genetics, University of Calgary, Calgary, AB, Canada T2N $4 \mathrm{~N} 1$

C E Jackson, Scott and White Clinic, Temple, TX 76508, USA

K G Monaghan, Department of Medical Genetics, Henry Ford Hospital, Detroit, Ml 48202, USA

S Gallinger, Familial Gastrointestinal Cancer Registry, Mount Sinai Hospital, Toronto, ON, Canada M5G 1 X5

D Huntsman, Department of Pathology and Laboratory Medicine, University of British Columbia, Vancouver, BC, Canada V6T 2B5

Conflict of interest: none declared.

*Please note that correspondence can be addressed to both the authors indicated.

\section{REFERENCES}

1 Karpeh MS, Kelsen DP, Tepper JE. Cancer of the stomach. In: DeVita VT, Hellman S, Rosenberg SA, eds. Cancer: principles and practice of oncology. 6th ed. Philadelphia: Lippincott, Williams and Wilkins, 2001:1092-126.

2 Lauren $\mathbf{P}$. The two histological main types of gastric carcinomas: diffuse and so-called intestinal-type carcinoma. Cancer 1965;70:50-5.

3 Machado JC, Soares P, Carneiro F, Rocha A, Beck S, Blin N, Berx G, Sobrinho-Simoes $M$. E-cadherin gene mutations provide a genetic basis for the phenotypic divergence of mixed gastric carcinomas. Lab Invest 1999;79:459-65.

4 Stemmermann GN, Nomura AM, Kolonel LN, Goodman MT, Wilkens LR. Gastric carcinoma: pathology findings in a multiethnic population. Cancer 2002;95:744-50

5 Stone J, Bevan S, Cunningham D, Hill A, Rahman N, Peto J, Marossy A, Houlston RS. Low frequency of germline E-cadherin mutations in familial and nonfamilial gastric cancer. Br J Cancer 1999:79:1935-37.

6 Keller G, Vogelsang H, Becker I, Hutter J, Ott K, Candidus S, Grundei T, Becker KF, Mueller J, Siewert JR, Hofler H. Diffuse type gastric and lobular breast carcinoma in a familial gastric cancer patient with an E-cadherin germline mutation. Am J Pathol 1999; 155:337-42.

7 Caldas C, Carneiro F, Lynch HT, Yokota J, Wiesner GL, Powell SM, Lewis FR, Huntsman DG, Pharoah PD, Jankowski JA, MacLeod P, Vogelsang H, Keller G, Park KG, Richards FM, Maher ER, Gayther SA, Oliveira C, Grehan N, Wight D, Seruca R, Roviello F, Ponder BA, Jackson CE. Familial gastric cancer: overview and guidelines for management. J Med Genet 1999;36:873-80.

8 Guilford P, Hopkins J, Harraway J, McLeod M, McLeod N, Harawira P, Taite $\mathrm{H}$, Scoular R, Miller A, Reeve AE. E-cadherin germline mutations in familial gastric cancer. Nature 1998;392:402-5.

9 Gayther SA, Gorringe KL, Ramus SJ, Huntsman D, Roviello F, Grehan N, Machado JC, Pinto E, Seruca R, Halling K, MacLeod P, Powell SM, Jackson CE, Ponder BA, Caldas C. Identification of germ-line E-cadherin mutations in gastric cancer families of European origin. Cancer Res 1998;58:4086-89.

10 Oliveira C, Bordin MC, Grehan N, Huntsman D, Suriano G, Machado JC, Kiviluoto T, Aaltonen L, Jackson CE, Seruca R, Caldas C. Screening Ecadherin in gastric cancer families reveals germline mutations only in hereditary diffuse gastric cancer kindred. Hum Mutat 2002;19:510-17.

11 Takeichi M. Morphogenetic roles of classic cadherins. Curr Opin Cell Biol 1995;7:619-27.

12 Machado JC, Oliveira C, Carvalho R, Soares P, Berx G, Caldas C, Seruca R, Carneiro $F$, Sobrinho-Simoes $M$. E-cadherin gene $(C D H 1)$ promoter methylation as the second hit in sporadic diffuse gastric carcinoma. Oncogene 2001;20:1525-8.

13 Berx G, Cleton-Jansen AM, Nollet F, de Leeuw WJ, van de Vijver M, Cornelisse C, van Roy F. E-cadherin is a tumour/invasion suppressor gene mutated in human lobular breast cancers. EMBO J 1995;14:6107-15.

14 Ewing B, Green P. Base-calling of automated sequencer traces using Phred. II. Error probabilities. Genome Res 1998;8:186-94.

15 Ewing B, Hillier L, Wendl MC, Green P. Base-calling of automated sequencer traces using phred. I. Accuracy assessment. Genome Res 1998;8:175-85.

16 Nickerson DA, Tobe VO, Taylor SL. PolyPhred: automating the detection and genotyping of single nucleotide substitutions using fluorescence-based resequencing. Nucleic Acids Res 1998;25:2745-51.

17 Gordon D, Abajian C, Green P. Consed: a graphical tool for sequence finishing. Genome Res 1998:8:195-202.

18 Suriano G, Oliveira C, Ferreira P, Machado JC, Bordin MC, De Wever O, Bruyneel EA, Moguilevsky N, Grehan N, Porter TR, Richards FM, Hruban R, Roviello F, Huntsman D, Mareel M, Carneiro F, Caldas C, Seruca R. 
Identification of $\mathrm{CDH} 1$ germline missense mutations associated with functional inactivation of the E-cadherin protein in young gastric cancer probands. Hum Mol Genet 2003; 12:575-82.

19 Suriano G, Mulholland D, de Wever O, Ferreira P, Mateus AR, Bruyneel E, Nelson CC, Mareel MM, Yokota J, Huntsman D, Seruca R. The intracellular Ecadherin germline mutation V832 M lacks the ability to mediate cell-cell adhesion and to suppress invasion. Oncogene 2003;22:5716-9.

20 Berx G, Cleton-Jansen AM, Strumane K, de Leeuw WJ, Nollet F, van Roy F Cornelisse C. E-cadherin is inactivated in a majority of invasive human lobula breast cancers by truncation mutations throughout its extracellular domain. Oncogene 1996;13:1919-25.

$21 \mathrm{Ng} \mathrm{PC}$, Henikoff S. Accounting for human polymorphisms predicted to affect protein function. Genome Res 2002;12:436-46.

22 Darwanto A, Kitazawa R, Maeda S, Kitazawa S. MeCP2 and promoter methylation cooperatively regulate $\mathrm{E}$-cadherin gene expression in colorectal carcinoma. Cancer Sci 2003;94:442-7.

23 Wijnhoven BP, Dinjens WN, Pignatelli M. E-cadherin-catenin cell-cell adhesion complex and human cancer. Br J Surg 2000;87:992-1005.

24 Salahshor S, Haixin L, Huo H, Kristensen VN, Loman N, Sjoberg-Margolin S, Borg A, Borresen-Dale AL, Vorechovsky I, Lindblom A. Low frequency of Ecadherin alterations in familial breast cancer. Breast Cancer Res 2001;3:199-207.

25 Becker KF, Atkinson MJ, Reich U, Becker I, Nekarda H, Siewert JR, Hofler H $\mathrm{E}$-cadherin gene mutations provide clues to diffuse type gastric carcinomas. Cancer Res 1994;54:3845-52.

26 Grady WM, Willis J, Guilford PJ, Dunbier AK, Toro TT, Lynch H, Wiesner G Ferguson K, Eng C, Park JG, Kim SJ, Markowitz S. Methylation of the CDHI promoter as the second genetic hit in hereditary diffuse gastric cancer. Nat Genet 2000;26:16-7.

27 Lichtenstein PHN, Verkasalo PK, lliadou A, Kaprio J, Koskenvuo M, Pukkala E, Skytthe A, Hemminki K. Environmental and heritable factors in the causation of cancer-analyses of cohorts of twins from Sweden, Denmark, and Finland. N Engl J Med 2000;343:78-85.

28 El-Omar EM, Carrington M, Chow WH, McColl KE, Bream JH, Young HA, Herrera J, Lissowska J, Yuan CC, Rothman N, Lanyon G, Martin M, Fraumeni JF Jr, Rabkin CS. Interleukin-1 polymorphisms associated with increased risk of gastric cancer. Nature 2000;404:398-402.

29 Shinmura K, Kohno T, Takahashi M, Sasaki A, Ochiai A, Guilford P, Hunter A Reeve $A E$, Sugimura $H$, Yamaguchi N, Yokota J. Familial gastric cancer: clinicopathological characteristics, RER phenotype and germline p53 and Ecadherin mutations. Carcinogenesis 1999;20:1127-31.

30 Aarnio M, Salovaara R, Aaltonen LA, Mecklin JP, Jarvinen HJ. Features of gastric cancer in hereditary non-polyposis colorectal cancer syndrome. Int J Cancer 1997;74:551-5

31 Heinimann K, Muller H, Weber W, Scott RJ. Disease expression in Swiss hereditary non-polyposis colorectal cancer (HNPCC) kindreds. Int J Cancer 1997;74:281-5.

32 Giardiello FM, Welsh SB, Hamilton SR, Offerhaus GJ, Gittelsohn AM, Booker SV, Krush AJ, Yardley JH, Luk GD. Increased risk of cancer in the Peutz-Jeghers syndrome. N Engl J Med 1987;316:1511-4.

33 Boardman L, Thibodeau SN, Schaid DJ, Lindor NM, McDonnell SK, Burgart $\sqcup$ Ahlquist DA, Podratz KC, Pittelkow M, Hartmann LC. Increased risk for cancer in patients with Peutz-Jeghers syndrome. Ann Intern Med 1998;128:896-9.

34 Bulow S, Alm T, Fausa O, Hultcrantz R, Jarvinen H, Vasen H, Bulow, S, Alm T, Fausa $O$, Hultcrantz R, Jarvinen $H$, Vasen $H$. Duodenal adenomatosis in familial adenomatous polyposis. DAF Project Group. Int I Colorectal Dis 1995; 10:43-6.

35 Wallace $M H$, Phillips RK. Upper gastrointestinal disease in patients with familial adenomatous polyposis. Br J Surg 1998;85:742-50.
36 Humar B, Toro T, Graziano F, Muller H, Dobbie Z, Kwang-Yang $\mathrm{H}$, Eng C, Hampel H, Gilbert D, Winship I, Parry S, Ward R, Findlay $M$, Christian A, Tucker M, Tucker K, Merriman T, Guilford P. Novel germline $\mathrm{CDH} 1$ mutations in hereditary diffuse gastric cancer families. Hum Mutat 2002;19:518-25.

37 Richards FM, McKee SA, Rajpar MH, Cole TR, Evans DG, Jankowski JA McKeown C, Sanders DS, Maher ER. Germline E-cadherin gene (CDH1) mutations predispose to familial gastric cancer and colorectal cancer. Hum Mol Genet 1999;8:607-10.

38 Guilford PJ, Hopkins JB, Grady WM, Markowitz SD, Willis J, Lynch H, Rajput A, Wiesner GL, Lindor NM, Burgart U, Toro TT, Lee D, Limacher JM, Shaw DW, Findlay MP, Reeve AE. E-cadherin germline mutations define an inherited cancer syndrome dominated by diffuse gastric cancer. Hum Mutat 1999; 14:249-55.

39 Dussaulx-Garin L, Blayau M, Pagenault M, Le Berre-Heresbach N, Raoul JL, Campion JP, David V, Bretagne JF. A new mutation of E-cadherin gene in familial gastric linitis plastica cancer with extra-digestive dissemination. Eur J Gastroenterol Hepatol 2001;3:711-5.

40 Yoon KA, Ku JL, Yang HK, Kim WH, Park SY, Park JG. Germline mutations of E-cadherin gene in Korean familial gastric cancer patients. J Hum Genet 1999:44:177-80.

41 Jonsson BA, Bergh A, Stattin P, Emmanuelsson M, Gronberg H. Germline mutations in E-cadherin do not explain association of hereditary prostate cancer, gastric cancer and breast cancer. Int J Cancer 2002;20:838-43.

42 Yabuta T, Shinmura K, Tani M, Yamaguchi S, Yoshimura K, Katai H, Nakajima T, Mochiki E, Tsujinaka T, Takami M, Hirose K, Yamaguchi A, Takenoshita S, Yokota J. E-cadherin gene variants in gastric cancer families whose probands are diagnosed with diffuse gastric cancer. Int I Cancer 2002; 10:434-41.

43 Pharoah PD, Guilford P, Caldas C. International Gastric Cancer Linkage Consortium. Incidence of gastric cancer and breast cancer in $\mathrm{CDH} 1$ (E-cadherin) mutation carriers from hereditary diffuse gastric cancer families. Gastroenterology 2001;121:1348-53.

44 Ooi BS, Ho YH, Eu KW, Seow Choen F. Primary colorectal signet-ring cell carcinoma in Singapore. ANZ J Surg 2001;71:703-6.

45 Mai KT, Isotalo PA, Guindi M, Burns BF, Parks W. Intestinal epithelial lesions associated with signet ring cell carcinoma of the colon and small intestine. Pathology 2002;34:51-6.

46 Alexander J, Watanabe T, Wu TT, Rashid A, Li S, Hamilton SR. Histopathological identification of colon cancer with microsatellite instability. Am J Pathol 2001;58:527-35

47 Rahman N, Stone JG, Coleman G, Gusterson B, Seal S, Marossy A, Lakhani SR, Ward A, Nash A, McKinna A, A'Hern R, Stratton MR, Houlston RS. Lobular carcinoma in situ of the breast is not caused by constitutional mutations in the E-cadherin gene. $\mathrm{Br} J$ Cancer 2000;82:568-70.

48 Huntsman DG, Carneiro F, Lewis FR, MacLeod PM, Hayashi A, Monaghan KG, Maung R, Seruca R, Jackson CE, Caldas C. Early gastric cancer in young, asymptomatic carriers of germ-line E-cadherin mutations. N Engl J Med 2001;344:1904-9.

49 Chun YS, Lindor NM, Smyrk TC, Petersen BT, Burgart $\amalg$, Guilford PJ, Donohue JH. Germline E-cadherin gene mutations. Is prophylactic total gastrectomy indicated? Cancer 2001;92:181-7.

50 Bevan S, Houlston RS. Genetic predisposition to gastric cancer. Q J Med 1999:92:5-10

51 Kaneda A, Kaminishi M, Yanagihara K, Sugimura T, Ushijima T. Identification of silencing of nine genes in human gastric cancers. Cancer Res 2002;62:6645-50. 